tific misconduct. Meanwhile Henry A. Waxman (Democrat, California), as chairman of the Health and Environment subcommittee, oversaw NIH from a distinctly liberal perspective trying, for example, to accommodate the views of AIDS activists, and to embarrass the tobacco industry whenever possible.

The new Energy and Commerce chairman is Tom J. Bliley Jr (Virginia) - the tobacco industry's staunchest defender in Congress and the man behind customs regulations that made it impossible for the United States to host an international AIDS conference. On the Senate side, the Labor and Human Resources committee that oversees NIH will be chaired by Nancy Landon Kassebaum (Kansas) instead of Edward M. Kennedy (Democrat, Massachusetts).

In his twilight years, Bill Natcher would sometimes drive out to NIH on Saturday mornings to gaze at the structure rising in his name, from where the agency will soon administer its $\$ 8$ billion-a-year extramural research programme across the United States.

There are Republicans in Congress who share his belief in the value of publicly funded health research. But there are others who will look coldly at the figures: they will see that federal support in this area almost doubled from 1984 to 1994 (from $\$ 4.7$ billion to just under $\$ 9$ billion, in constant 1987 dollars), and that the US government now spends 18 per cent of its $R \& D$ budget on health - more than twice as much as Germany, Britain or Japan. They will ask how much gratitude Congress got for this: how often, for example, a successful researcher explained on television that his or her work was paid for entirely by the federal government. And they will conclude that, for better or worse, the Natcher era is over.

Colin MaCilwaIn Senior US correspondent, Nature

\title{
Japan on verge of first gene therapy trial
}

Almost five years after the first human gene therapy trials were carried out in the United States, Japan is set to approve its first use of the technology. Hindered by the lack of a substantial biotechnology industry and still awaiting formal government approval, Japanese gene therapy has been relatively slow to get off the ground. But for the first time both a proposed clinical trial and the committees necessary to endorse it are in place. 1995 seems to be the year in which gene therapy will finally make its appearance in Japan.

The Japanese Ministry of Health and Welfare released its first gene therapy guidelines in April 1993. These restricted applications to somatic cells and to the treatment of otherwise incurable conditions. They also established a committee to consider proposed applications. But developments since then have been slow. The Ministry of Education, Science and Culture, which oversees Japan's universities, has also insisted on having a say and on setting up its own committee. Members of the education committee were not announced until last February and only met for the first time at the end of April.

The first formal application, to carry out a gene therapy trial has been made by Yukio Sakiyama at the Hokkaido University School of Medicine in northern Japan. Last summer Sakiyama was given clearance by the university's medical ethics committee to treat a boy (now 4 years old) suffering from adenosine deaminase (ADA) deficiency, which causes weakening of the immune system. $\mathrm{He}$ is now seeking approval from the two government committees. As Nature Medicine went to press, a joint working

\section{JAPAN}

group, made up of members from both ministry committees in addition to invited experts, was due to meet on 21 December to consider the scientific merits of the proposal. Both Sakiyama and a member of the working group said they were confident that the proposal would pass this time.

If it leaps this hurdle successfully, Sakiyama's application will then be passed on to the full committees of both the health and education ministries, which will consider the ethical aspects. Assuming a quick passage through the joint working group, these meetings could take place as early as January and the chances of final approval during early 1995 look good.

Gene therapy frequently requires the use of a vector, usually a virus, to carry the therapeutic gene into the patient's cells. A lack of a suitable vector in Japan has meant that Sakiyama has had to turn to the United States, where Genetic Therapy Inc. of Gaithersburg, Maryland, produces the retroviral vector he plans to use. Although the vector is already authorized for use in the United States by the Food and Drug Administration, Sakiyama will still have to get special approval for its export once he has clearance from the Japanese government.

The vector's basic safety and effectiveness in ADA-deficient patients have already been demonstrated by Michael Blaese and colleagues at the US National Institutes of Health. The hope is that by using a proven method from abroad, Japan can enjoy a safe and relattvely uncontroversial introduction to this form of treatment.
Other similar projects are also in the regulatory pipeline. The next is likely to be by Kiyoshi Takatsuki of Kumamoto University in westem Japan, who is collaborating with another US-based biotechnology company, Viagene Inc. of San Diego, California, and Midori Juji (Green Cross Corporation) in Osaka. He plans to treat HIV-positive patients with a vector, based on the murine leukaemia virus, which has been in use in the United States for about a year. Consideration of the proposal by his university medical eth Ics committee has just begun.

Yoshiakd Moriyama at Niigata University, north of Tokyo, is waiting for a suitable leukaemia patient before applying for permission for his gene therapy trial. He plans to use a bacterial neomycin resistance gene to label bone marrow stem cells that have been removed from the patient and heat treated. Once the cells are reintroduced, the marker gene will show whether any recurrences are due to malignant cells that were removed from the patient but survived the heat treatment or from cells that were not removed at all.

Official approval of gene therapy in Japan has been slow in coming but it is seen as a particularly important development for Japanese medicine and all sides agree that it needs to be dealt with carefully. Japanese doctors have traditionally found the formal procedures that govern clinical trials to be fairly unrestrictive (see p. 12). The health ministry sees the introduction of gene therapy as a valuable opportunity to exert greater control over the conduct of clinical trials, which will be necessary if Japan is to harmonize its regulations with those of other countries.

TIMO HANNAY

Hannay is a freelance writer based in Tokyo 